\title{
Canada can override patents to combat drug, equipment shortages during the pandemic
}

\author{
n Cite as: CMAJ 2020 April 20;192:E438-9. doi: 10.1503/cmaj.1095862
}

Posted on cmajnews.com on April 2, 2020

$\mathbf{T}$ he federal government now has additional powers to override patents for drugs, vaccines and medical equipment as needed to secure critical supplies during the COVID-19 pandemic.

Amendments to the Patent Act under Canada's COVID-19 Emergency Response Act make it possible for the federal government - or anyone it designates - to make, use and sell patented inventions "to the extent necessary to respond to a public health emergency."

Effectively, the act enables Ottawa to combat price gouging or shortages of any needed product, from vaccines to ventilators, by licensing companies to make generic copies of brand-name products without having to negotiate with patent holders. These compulsory licences would last only a year, and patent holders would receive "adequate" compensation, to be determined after the fact.

According to Innovation, Science and Economic Development Canada, the new rules are intended to ensure that patents are not a barrier to securing supplies during the pandemic.

Health Canada will also speed up its regulatory process for any vaccine or therapeutic product intended to treat COVID-19, including reviews of drug submissions and clinical trial applications.

"This piece of legislation is a good response to the emergency that we're facing," said Dr. Joel Lexchin, professor emeritus of Health Policy and Management at York University in Toronto. He noted that some countries like Australia are already experiencing shortages of critical medicines due to panic buying.

Canada's deputy health minister recently warned that disruptions in global

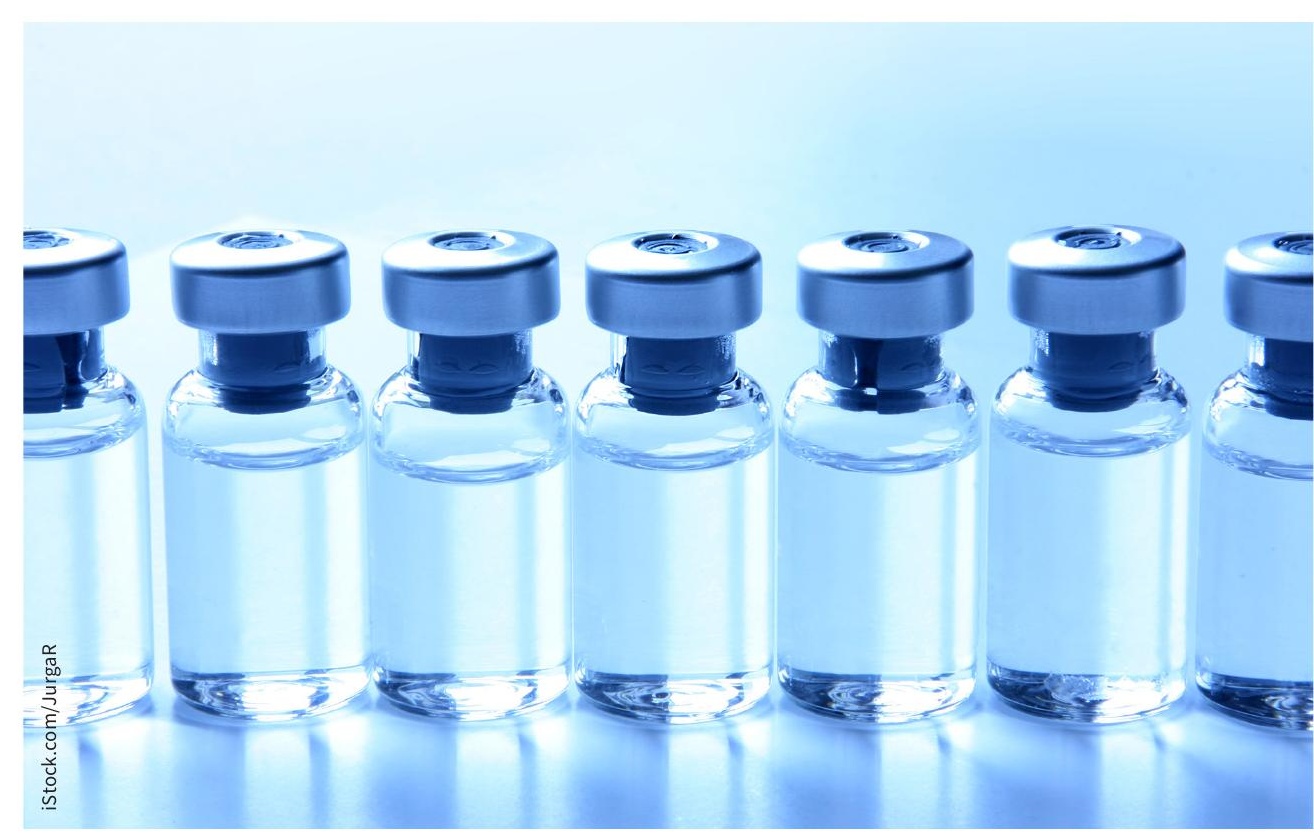

Provisions of recent emergency legislation will make it easier for Canada to issue compulsory licences for medical products.

supply chains during the pandemic will likely cause drug shortages here too.

"The Patent Act should not stand in the way of emergencies of this nature," said Philip Kerr, an Ottawa patent and trade lawyer. Previously, Canada's patent commissioner had discretion over whether to authorize the government to use patented products during emergencies, and the government had to prove it had tried to work out a deal with the patent holder first. There are no such conditions under the new legislation.

The new rules also enable Ottawa to specify third parties to make, use and sell patented products. Kerr said this change should embolden smaller companies to apply to build ventilators or other critical medical devices during the pandemic.
Brand-name pharmaceutical companies have opposed previous Canadian efforts to authorize third parties to make and sell patented products, also known as compulsory licensing.

In this case, the industry's main concern is that "the government does not have to check with the original manufacturer to see if they can supply a product," said Sarah Dion-Marquis of Innovative Medicines Canada, the national association for brand-name drug companies. "That said, the time limitation in the amendment clearly recognizes that this is an extraordinary measure intended only for potential use during the current public health crisis."

Jim Keon, president of the Canadian Generic Pharmaceutical Association, welcomed the new measures as "prudent 
and reasonable." In a statement, Keon noted that international trade agreements to which Canada is party uphold the ability of countries to issue compulsory licences for medicines and other urgently needed items to respond to a health crisis.

According to Lexchin, the biggest challenge generic companies may face if they are asked to produce patented medicines is a potential shortage of active ingredients from major producers like India and China.

India, home to the world's largest drug manufacturers, has banned the export of 26 pharmaceutical ingredients and products because of shortages in their supply. The export ban includes the antimalarial drug hydroxychloroquine, which is being studied in clinical trials as a potential treatment for COVID-19.

Generic drug companies are closely monitoring their orders and inventories, said Jeff Connell, vice-president of corporate affairs at the Canadian Generic Pharmaceutical Association. He did not comment directly on any shortages of active ingredients.

"Our industry is also working with our international partners to mitigate the potential for shortages in Canada," Connell said.

Laura Eggertson, Wolfville, N.S. 